31. Teuten, E. L. et al., Transport and release of chemicals from plastics to the environment and to wildlife. Philos. Trans. R. Soc. B: Biol. Sci., 2009, 364(1526), 2027-2045.

32. Colborn, T., vom Saal, F. S. and Soto, A. M., Developmental effects of endocrine-disrupting chemicals in wildlife and humans. Environ. Health Persp., 1993, 101(5), 378-384.

33. Marples, N. M. and Roper, T. J., Effects of novel colour and smell on the response of naïve chicks towards food and water. Anim. Behav., 1996, 51(6), 1417-1424.

34. Guptha, M. B., Vijayan, L., Sandaliyan, S. and Sridharan, N., Status of wetlands and wetland birds in Coimbatore, Trichy, Perambalore and Thiruvarur Districts in Tamil Nadu, India. World J. Zool., 2011, 6(2), 154-158.

35. MUD, Coimbatore Solid Waste Management Project under JnNURM, City Report. Ministry of Urban Development Government of India, July 2013, p. 19.

36. Pettit, T. N., Grant, G. S. and Whittow, G. C., Ingestion of plastics by Laysan albatross. Auk, 1981, 98, 839-841.

37. Fry, D. M., Fefer, S. I. and Sileo, L., Ingestion of plastic debris by Laysan albatrosses and wedge-tailed shearwaters in the Hawaiian Islands. Mar. Pollut. Bull., 1987, 18(6), 339-343.

38. Furness, R. W., Ingestion of plastic particles by seabirds at Gough Island, South Atlantic Ocean. Environ. Pollut. A, Ecol. Biol., 1985, 38(3), 261-272.

39. Ryan, P. G. and Jackson, S., The lifespan of ingested plastic particles in seabirds and their effect on digestive efficiency. Mar. Pollut. Bull., 1987, 18(5), 217-219.

40. Xu, S. Y., Zhang, H., He, P. J. and Shao, L. M., Leaching behaviour of bisphenol: A from municipal solid waste under landfill environment. Environ. Technol., 2011, 32, 1269-1277.

41. Parslow, J. L. F. and Jefferies, D. J., Elastic thread pollution of puffins. Mar. Pollut. Bull., 1972, 3(3), 43-45.

42. Cole, M., Lindeque, P., Halsband, C. and Galloway, T. S., Microplastics as contaminants in the marine environment: a review. Mar. Pollut. Bull., 2011, 62(12), 2588-2597.

43. Martin, W. et al., Microplastics in freshwater ecosystems: what we know and what we need to know. Environ. Sci. Eur., 2014, 26, 12; doi:10.1186/s12302-014-0012-7.

44. Azzarello, M. Y. and Van Vleet, E. S., Marine birds and plastic pollution. Mar. Ecol-Progr. Ser., 1987, 37, 295-303.

45. Ryan, P. G., The effects of ingested plastic on seabirds: correlations between plastic load and body condition. Environ. Pollut., 1987, 46(2), 119-125.

46. Seedikkoya, K., Azeez, P. A. and Shukkur, E. A. A., Cattle Egret Bubulcus ibis habitat use and association with cattle. Forktail, 2005, 21, 174.

47. Santharam, V., Indian pond-herons Ardeola grayii feeding on dragonflies. J. Bombay Nat. Hist. Soc., 2003, 100(1), 108.

ACKNOWLEDGEMENTS. We are grateful to Dr K. Ramasamy (then Vice Chancellor, TNAU) for permitting this study in TNAU Campus. We thank Dr P. Balasubramanium (Department of Biochemistry, TNAU), Dr Shirish S. Manchi and Dr M. Mahendiran (SACON) for their support. We also thank Mr Avadhoot Dilip Velankar, Mr M. J. Riyas and Ms Anju R. Panickar for assistance with QGIS software. Our special thanks to M/s Mukesh Lal Das, Gopesh Sharma, and Manish Kumar for their assistance during the study.

Received 16 July 2019; revised accepted 8 November 2019

doi: $10.18520 / \mathrm{cs} / \mathrm{v} 118 / \mathrm{i} 6 / 977-983$

\section{Tunnel wells, the traditional water harvesting structures of Kasaragod, Kerala: re-visited}

\author{
E. Shaji ${ }^{1, *}$, K. V. Sarath ${ }^{1}$, Pranav Prakash ${ }^{1}$, \\ Adithya Pazhoor Abraham ${ }^{2}$, V. Deepchand, \\ V. Kunhambu ${ }^{3}$ and A. P. Pradeepkumar ${ }^{1}$ \\ ${ }^{1}$ Department of Geology, University of Kerala, \\ Thiruvanathapuram 695 581, India \\ ${ }^{2}$ Department of Civil Engineering, National Institute of Technology, \\ Calicut 673 601, India \\ ${ }^{3}$ Central Ground Water Board, Kerala Region, \\ Thiruvanathapuram 695 004, India
}

Tunnel wells or surangams are less common traditional groundwater harvesting structures of Kasaragod district in Kerala, southern India. These horizontal wells, structurally resembling Qanats, are driven into the laterite plateaus and hills for tens of metres. The status of tunnel wells of Kasaragod is synthesized, the problems and prospects examined to evolve a common strategy for sustainability. Functionally four different types of tunnel wells exist: (1) single tunnel, (2) single tunnel with branches, (3) tunnel system ending in a vertical well, and (4) tunnel system ending in a well with a horizontal outlet. The yield of tunnel wells has reduced over the years and $50 \%$ of them are now dry. Single tunnels (types 1 and 2) act as conduits for excessive draining of groundwater from the aquifer system during the rainy season, leading to wastage of groundwater and lowering the water table. The discharge estimates from the 24 tunnel wells indicate that $6653 \mathrm{~m}^{3}$ of groundwater gets discharged from the aquifer per day. To prevent wastage, the mouth of the tunnel wells should be fitted with half shutter gate with a control valve at the bottom. There is an urgent need to create awareness to protect and modify these traditional water harvesting structures for sustainability of water resources.

Keywords: Discharge, groundwater, Kasaragod, traditional water harvesting, tunnel wells, surangam.

TRADITIONAL water harvesting structures generally provide time-tested solutions to water scarcity problems in many parts of India $^{1-6}$. Tunnel wells or surangams are less well known and are gradually disappearing traditional groundwater harvesting structures of Kasaragod district, Kerala, southern India ${ }^{6-11}$. The word surangam is derived from a Kannada word for tunnel. It is also known as thurangam, thorapu, malayoottu, etc. These horizontal wells driven into the laterite plateaus and hills, structurally resemble Qanats ${ }^{1}$ found in the arid regions of south-western Asia and North Africa, running several kilometres underground and are in use since generations. Probably the

*For correspondence. (e-mail: shajigeology@gmail.com) 

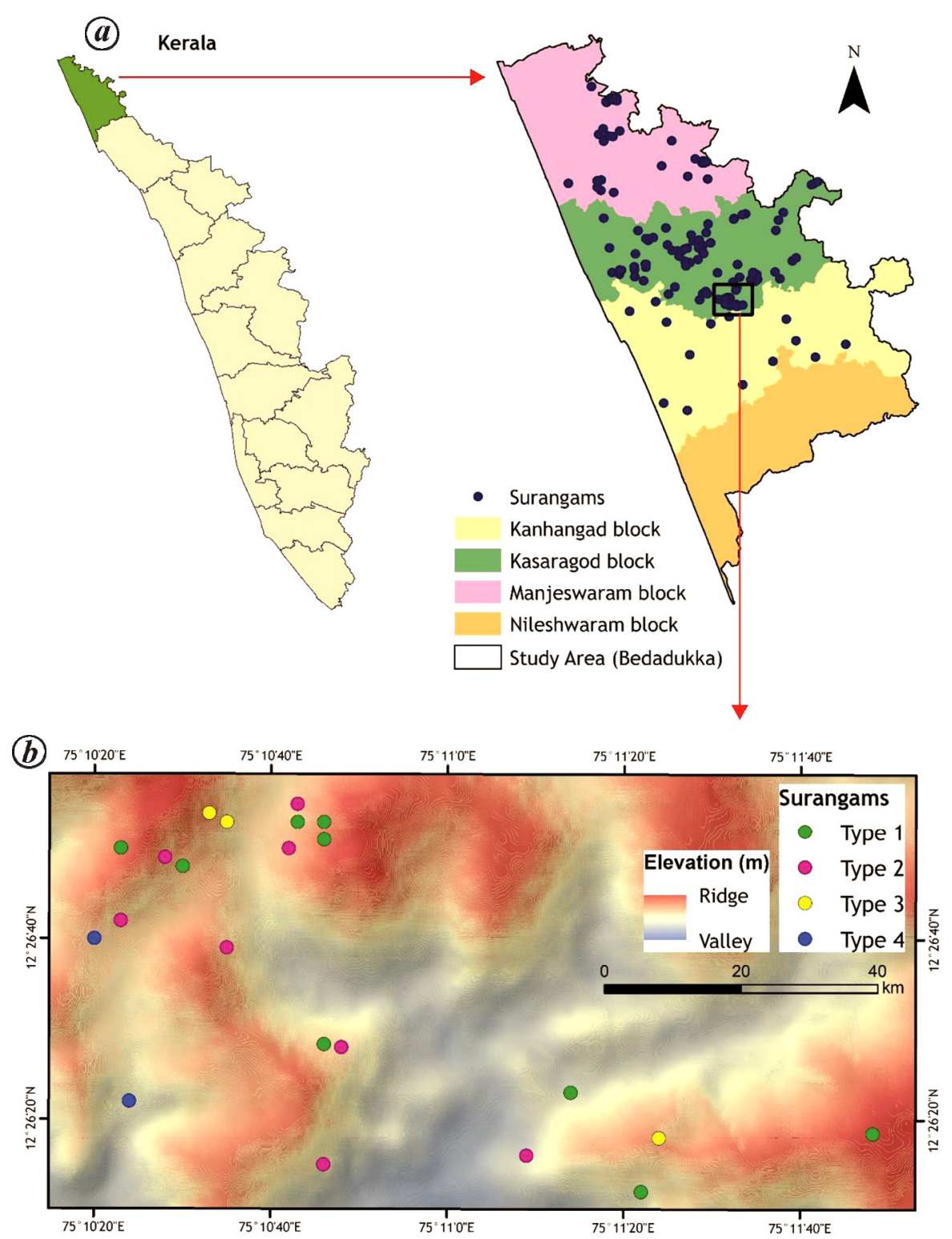

Figure 1. $\boldsymbol{a}$, Location map with the distribution of tunnel wells in Kasaragod district. $\boldsymbol{b}$, Study area, Bedadukka panchayat, shows the ridges and valleys and different types of tunnel wells.

expertise for these structures had come to India through Arabs who settled in the Malabar Coast at the end of 17 th century ${ }^{6,7,11,12}$. Groundwater discharged through surangams is either directly used or collected in open ponds/ wells. Despite their declining use, they continue to be the lifeline for a large number of farmers in Kasaragod.

The present study examines the status of the tunnel wells in Kasaragod (Figure $1 a$ ) with a case study from Bedadukka panchayat (Figure $1 b$ ). The study area falls in the Survey of India toposheet number $49 \mathrm{Y} / 15+\mathrm{P} / 3$, between $12^{\circ} 26^{\prime} 15^{\prime \prime} \mathrm{E}$ and $12^{\circ} 26^{\prime} 55^{\prime \prime} \mathrm{E}$ and $75^{\circ} 10^{\prime} 20^{\prime \prime} \mathrm{N}$ and $75^{\circ} 11^{\prime} 50^{\prime \prime} \mathrm{N}$ (Figure $1 \mathrm{~b}$ ). The topography depicting the ridges and valleys and locations of the different types of surangams are shown in Figure $1 b$. The Bedadukka area is a hydro-geologically closed basin. This small basin
(Figure $1 \mathrm{~b}$ ) having $4.4 \mathrm{sq} . \mathrm{km}$ area with water level fluctuation (pre- and post-monsoon) of two metres and specific yield of aquifer of 0.03 may have a groundwater reserve up to $264,000 \mathrm{~m}^{3}$. In the past, villagers depended on different types of tunnel wells for all their water requirements, both domestic and irrigation. However, now they depend on bore wells/dug wells and only partly on surangams.

The lateritic mount has a small flat terrace at the summit. This and the sloppy area of hills are the recharge areas for tunnel wells. Habitation is confined to the slopes, where the tunnel mouth opens out. Seven hundred and sixty surangams in Kasaragod, Kanhangad and Manjeswaram blocks were examined in this study (Figure $1 \mathrm{~b}$ ). Thirty per cent of them were abandoned. Drastic and 
unscientific changes in the land-use pattern were noticed all along the laterite mounds. These age-old structures are ill-maintained, and the dumping of non-degradable waste inside the air vents chokes and restricts the flow of water.

The tunnel wells start as a trench across the slope of the hill and ends in the middle of the hillock. They are unlined horizontal structure in laterite and have the innate strength to withstand caving. The average width and height of the tunnel is 0.4 to $1.0 \mathrm{~m}$ and 1.5 to $2 \mathrm{~m}$ respectively. The length varies from 10 to $30 \mathrm{~m}$ depending on the availability of groundwater. Most of their outlets are at lower elevations, so that water flows under gravity. The different types of tunnel wells are shown in Figure $2 a-c$. There were mainly four types of tunnel wells in the study area.

Type 1 -Single tunnel wells: They are the simplest structures as shown in Figure $2 a$. They are commonly seen in areas with homogeneous lateritic cover along the slope. They are mostly used for domestic and irrigation purposes.

Type 2 - Single tunnel with branches: It is a tunnel system with several tunnels arranged in different orientations, which are interconnected. If the surangam is very long, a number of vertical air shafts are provided to ensure ventilation within the tunnels. It is commonly seen in areas with heterogeneous laterite and often ends in

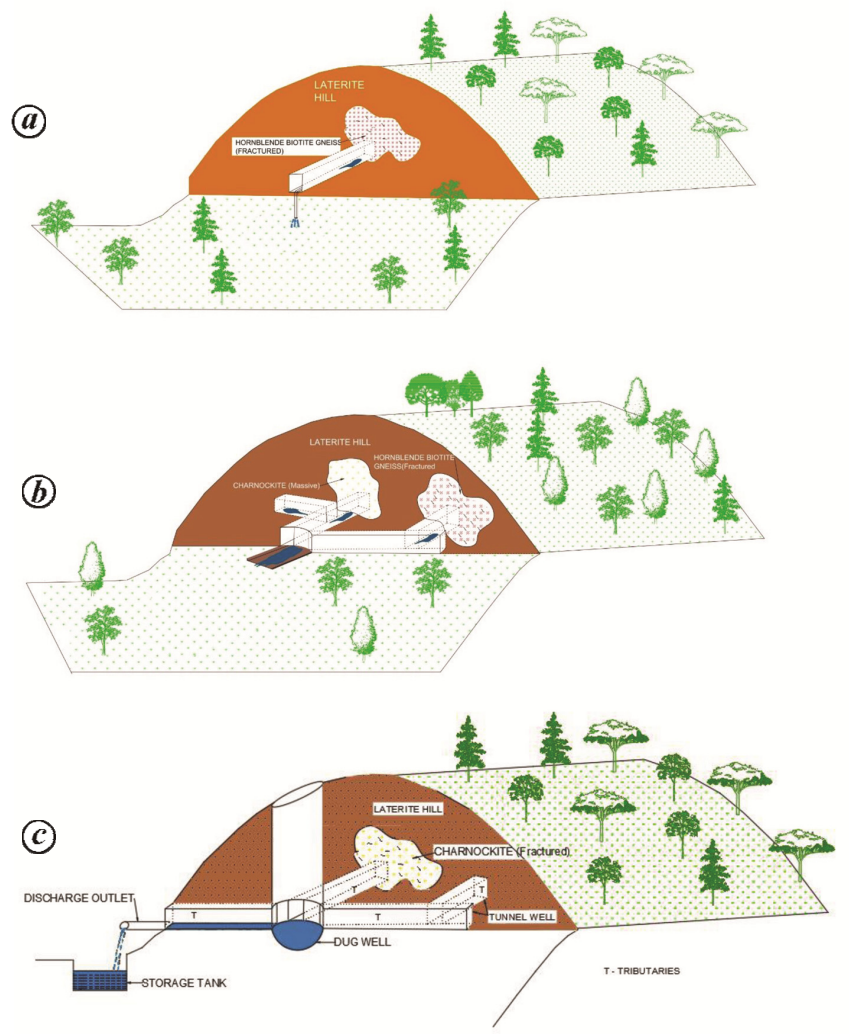

Figure $2 \boldsymbol{a}-\boldsymbol{c}$. Diagram of different types of tunnel wells of the study area. boulders of massive crystalline rocks. Tunnels are driven in different directions to tap more groundwater (Figure $2 b)$.

Type 3 - Tunnel system ending in a vertical well: This works as a dug well to store the groundwater tapped by tunnels from different directions from the hill. Generally, it is located at a higher elevation and little away from habitations. This type is the most suitable and sustainable type of structure. But most such structures in the area are now becoming dry during summer (Figure $2 c$ ).

Type 4 - Tunnel system ending in a well with a horizontal outlet: This is same as type 3 . However, the dug well has an outlet in this system to drain the water downstream (Figure $2 c$ ). These types are mostly used for irrigation purposes.

The rainwater captured by the entire sub-watershed gradually and steadily seeps out through these tunnel wells. The discharge (yield) from a tunnel well depends on its length and the thickness of the saturated lateritic zone. The groundwater yield of tunnel wells will be maximum and minimum during rainy season and peak summer respectively. The discharge from a tunnel at a particular time can be calculated by using the following formula with the assumption that the tunnel face has a rectangular notch.

$$
Q=3.33(L-0.2 H) H^{1.5},
$$

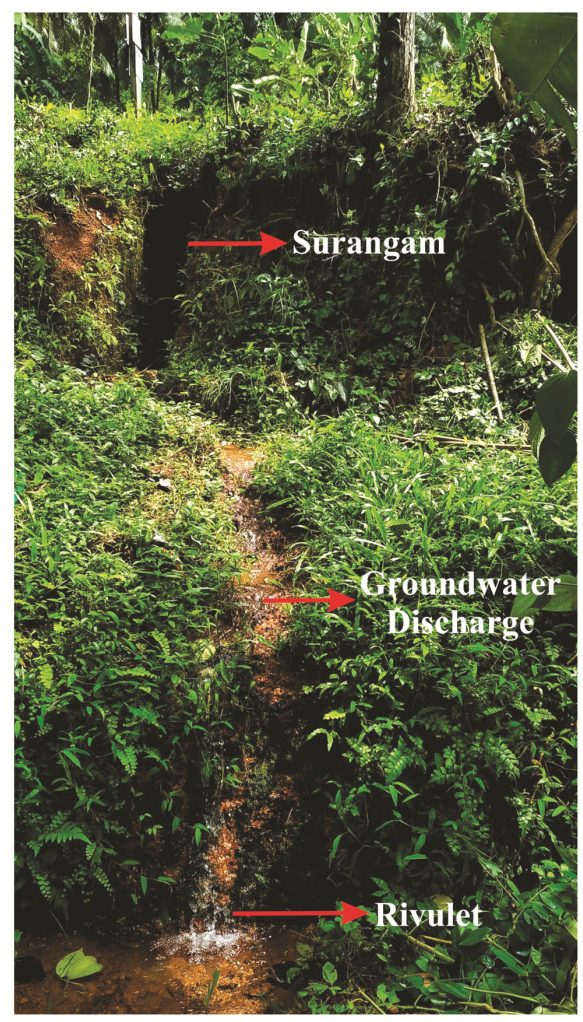

Figure 3. Groundwater discharge from tunnel wells to the rivulet during monsoon. 
RESEARCH COMMUNICATIONS

Table 1. Yield details of tunnel wells in different periods with GPS readings

\begin{tabular}{|c|c|c|c|c|c|}
\hline Tunnel well no. & Latitude & Longitude & $\begin{array}{l}\text { Discharge litre/day } \\
\text { (May 2001) (ref. 8) }\end{array}$ & $\begin{array}{c}\text { Discharge litre/day } \\
\text { (May 2019) }\end{array}$ & $\begin{array}{c}\text { Discharge litre/day } \\
\text { (August 2019) }\end{array}$ \\
\hline $\mathrm{T} 1$ & 12.445 & 75.1730 & 17,280 & 280 & 345,600 \\
\hline $\mathrm{T} 2$ & 12.4469 & 75.1744 & 25,920 & Dry & 172,800 \\
\hline T3 & 12.4466 & 75.175 & 172,800 & 2,187 & 691,200 \\
\hline $\mathrm{T} 4$ & 12.4483 & 75.1758 & 86,400 & 3,323 & 518,400 \\
\hline T5 & 12.4480 & 75.1763 & 129,600 & 463 & 432,000 \\
\hline T8 & 12.4475 & 75.1794 & No flow & Closed & Closed \\
\hline T9 & 12.4486 & 75.1786 & 8,640 & 13,292 & 172,800 \\
\hline $\mathrm{T} 10$ & 12.4480 & 75.1794 & 8,640 & Closed & Closed \\
\hline $\mathrm{T} 11$ & 12.4472 & 75.1783 & 8,640 & 659 & 172,800 \\
\hline $\mathrm{T} 12$ & 12.4441 & 75.1763 & 17,280 & No flow & 345,600 \\
\hline $\mathrm{T} 14$ & 12.4472 & 75.1730 & 8,640 & Dry & 172,800 \\
\hline $\mathrm{T} 15$ & 12.4444 & 75.1722 & 64,800 & Dry & 172,800 \\
\hline $\mathrm{T} 17$ & 12.4411 & 75.18 & 17,280 & Dry & 345,600 \\
\hline $\mathrm{T} 18$ & 12.4411 & 75.18 & 17,280 & Dry & 345,600 \\
\hline T19 & 12.4583 & 75.1875 & 17,280 & No flow & 345,600 \\
\hline T20 & 12.4383 & 75.19 & 8,640 & Dry & 345,600 \\
\hline $\mathrm{T} 21$ & 12.4205 & 75.1733 & Dry & Dry & 172,800 \\
\hline $\mathrm{T} 22$ & 12.4366 & 75.1894 & 8,640 & Not in use & 172,800 \\
\hline T23 & 12.4394 & 75.1733 & 17,280 & 2,400 & 345,600 \\
\hline $\mathrm{T} 24$ & 12.4397 & 75.1872 & 8,640 & 178 & 172,800 \\
\hline $\mathrm{T} 25$ & 12.4377 & 75.1858 & 17,280 & Not in use & 345,600 \\
\hline \multirow[t]{2}{*}{ T26 } & 12.4384 & 75.1967 & 86,400 & 199 & 518,400 \\
\hline & Total & & 764,640 & 23,274 & $6,652,800$ \\
\hline
\end{tabular}
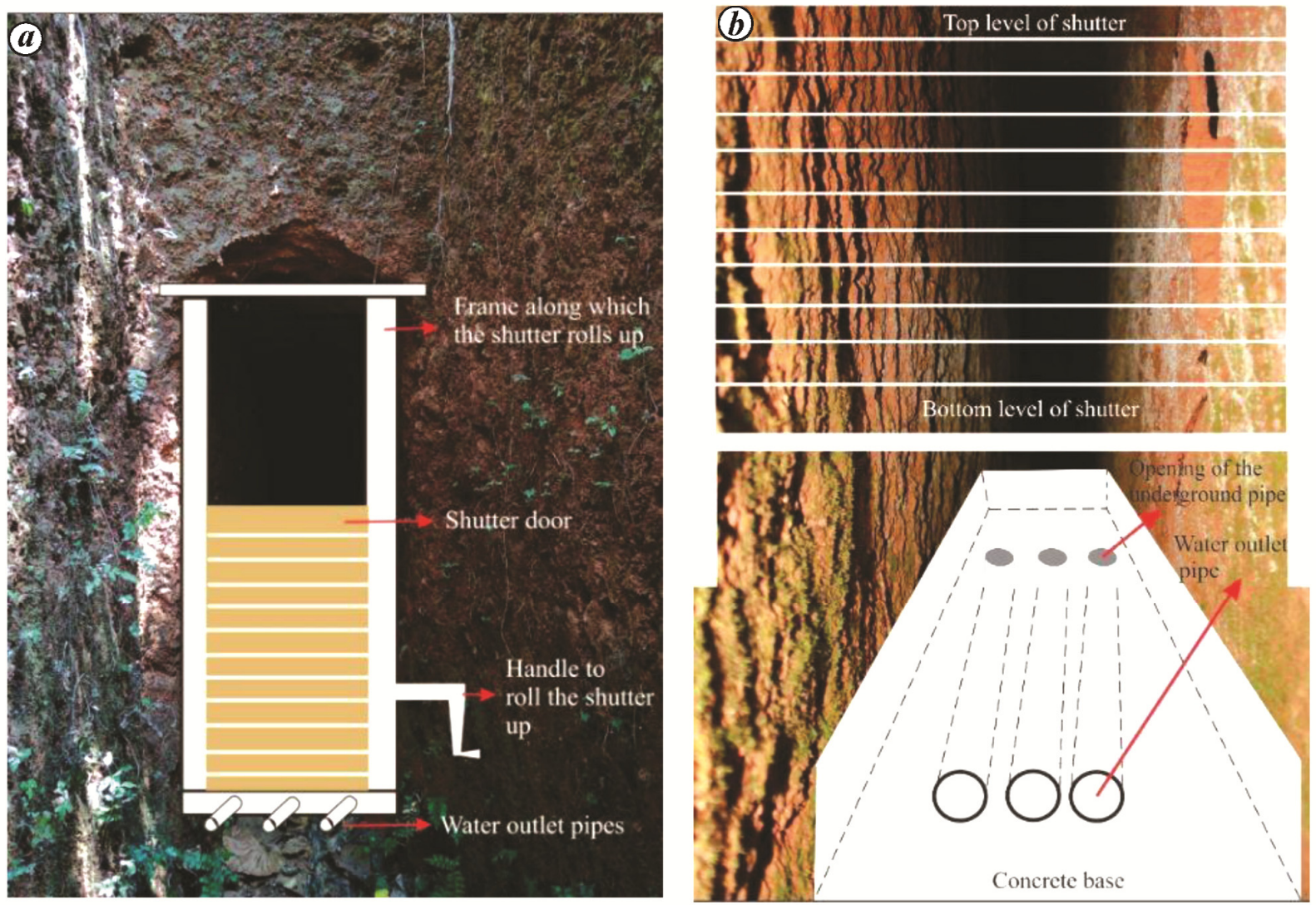

Figure $4 \boldsymbol{a}, \boldsymbol{b}$. Design of the shutter gate proposed in the study to close/regulate the discharge of groundwater from tunnel wells. 
where $Q$ is the flow of water (discharge) $\left(\mathrm{m}^{3} / \mathrm{sec}\right), L$ the width of the tunnel face (m) and $H$ is the height of the flowing water above the base of the tunnel $(\mathrm{m})$.

Detailed inventory of 24 tunnel wells was made during May and August 2019 (Table 1). Historical data of 2001 is also given in Table 1. The present yield of these wells was compared with the data of 2001 (ref. 8). The data showed that the yield of the tunnel wells had reduced considerably over the years. The total discharge during 2001 (summer) was $756 \mathrm{~m}^{3}$ whereas during 2019 it reduced to $23 \mathrm{~m}^{3}$. However, during monsoon (August 2019), these tunnel wells discharged large quantities of groundwater at the rate of 3 to $12 \mathrm{l} / \mathrm{sec}$. A tunnel well with a yield of $8 \mathrm{l} / \mathrm{sec}$ discharges about $691 \mathrm{~m}^{3}$ $(691,0001)$ of groundwater per day. Similarly, it was observed that all the single tunnel wells in and around the Bedadukka panchayat were discharging huge quantities of groundwater during rainy season and this water reached the thodu or rivulet (Figure 3), thereby escaping to the sea. The estimate done during August 2019, revealed that about $6653 \mathrm{~m}^{3}$ of groundwater was being discharged from the aquifer per day (Table 1). Hence 50 to 60 such leaking tunnel wells may be sufficient to drain the whole aquifer in a short period.

To prevent undesirable loss of groundwater, we recommend that the mouth of the tunnel wells be blocked with half shutter gate, an engineering structure designed in this study, having a control valve at the bottom. This gate looks like a normal shutter with concrete frames on both sides (Figure $4 a$ ). The handle attached to the frame can be used to roll the shutter up and down. The tunnel is floored with concrete. Three pipes may be installed in the concrete at the base, as shown in Figure $4 b$, serving as outlets. The inlets of the pipes should have sieves to prevent leaves and other solids from entering. The outlet should have a control valve. With this kind of a stutter gate facility, the tunnel can act as a proper groundwater reservoir (Figure $4 a$ and $b$ ). To monitor the height of the impounded water, a pressure gauge can be fitted to the outlet pipe. The whole structure will act as a storage tank after modification.

Construction of new tunnel wells should be discouraged in the region. The panchayat authorities should collect details of all the existing tunnel wells in their respective panchayats, and the data should be brought to a digital (spatio-temporal) platform. There is a pressing need to create awareness about restoring and reviving these traditional water harvesting structures. These are not only far more sustainable in the long run than bore wells, but also carry with them the age-old wisdom of treating nature with respect and using natural resources wisely.

1. Agarwal, A. and Narain, S., Dying Wisdom: Rise, Fall and Potential of India's Traditional Water Harvesting Systems, Centre for Science and Environment, New Delhi, 1997, pp. 117-125.

2. Nair, G. U., Traditional wisdom in harvesting water. J. Tradit. Folk Pract., 2016, 4(1), 50-53.

3. Balakrishnan, K. and Saritha, S., Groundwater Information Booklet of Kasaragod District, Kerala State. Central Ground Water Board, Ministry of Water Resources, Government of India, Trivandrum, 2007, pp. 1-22.

4. Padre, S., Farming without pumps. Leisa India, AME Foundation, Bangalore, India, 2008, pp. 34-35.

5. Basak, P., Raghavendra Prasad, P. M. and Sreedharan, K. E., Surangams - a traditional water harvesting system in North Malabar. Centre for Science and Environment, Thomson Press Limited, Faridabad, India, 1997, pp. 222-223.

6. Crook, D., Tripathi, S. and Jones, R. T., The sustainability of suranga irrigation in South Karnataka and northern Kerala, India. In First World Irrigation Forum, Conference Proceedings, Mardin, Turkey, 2013, pp. 50-55.

7. Balooni, K., Kalro, A. H. and Ambili, K. G., Sustainability of tunnel wells in a changing agrarian context: a case study from South India. Agric. Water Manage., 2010, 97(5), 659-665.

8. Nayak, N. C., Study on age old non-conventional adit/tunnel wells in the lateritic terrain of Kasaragod district, Kerala. Central Ground Water Board, Trivandrum, 2001, pp. 1-20.

9. Crook, D., Tripathi, S. and Jones, R. T., An investigation into the age and origin of suranga in the foothills of the Western Ghats of India. Water History, 2015, 7(3), 253-270.

10. Halemane, H., Suranga a sustainable water resource. In National Seminar on Water and Culture, Hampi, Bellary, India, 2007, pp. 20-25.

11. Prasad, P. M. R., Jayakumar, N. S. and Basalt, P., Surangams of Kasargod - an unconventional water harvesting mechanism. Centre for Water Resources Development and Management, Kunnamangalam, Kozhikode, Kerala, 1991, pp. 40-45.

12. Nazimuddin, M. and Kokkal, K., Studies on development of surangams as a nonconventional water resource in the Kanhangad block panchayat, Kasaragod district, Kerala. Groundwater Division, Centre for Water Resources Development and Management, Kunnamangalam, Kozhikode, Kerala, India, 2002, pp. 1-50.

ACKNOWLEDGEMENTS. Project funded by KSCSTE, Govt of Kerala on 'Arsenic contamination groundwater' (KSCSTE/5979/2017 E\&E dated 9-11-2018) is acknowledged. The comments of the reviewer have improved the manuscript considerably.

Received 25 August 2019; revised accepted 25 November 2019

doi: $10.18520 / \mathrm{cs} / \mathrm{v} 118 / \mathrm{i} 6 / 983-987$ 